\title{
Three GABA Receptor-Mediated Postsynaptic Potentials in Interneurons in the Rat Lateral Geniculate Nucleus
}

\author{
J. Julius Zhu' ${ }^{1,2}$ and Fu-Sun Lo' \\ 1Shanghai Brain Research Institute and Institute of Neuroscience, Chinese Academy of Sciences, Shanghai 200031, \\ China, and ${ }^{2}$ Abteilung Zellphysiologie, Max-Planck-Institut für medizinische Forschung, Heidelberg D-69120, Germany
}

Inhibition is crucial for the thalamus to relay sensory information from the periphery to the cortex and to participate in thalamocortical oscillations. However, the properties of inhibitory synaptic events in interneurons are poorly defined because in part of the technical difficulty of obtaining stable recording from these small cells. With the whole-cell recording technique, we obtained stable recordings from local interneurons in the lateral geniculate nucleus and studied their inhibitory synaptic properties. We found that interneurons expressed three different types of GABA receptors: bicuculline-sensitive $\mathrm{GABA}_{A}$ receptors, bicuculline-insensitive $\mathrm{GABA}_{A}$ receptors, and $\mathrm{GABA}_{B}$ receptors. The reversal potentials of GABA responses were estimated by polarizing the membrane potential. The $\mathrm{GABA}_{\mathrm{A}}$ receptor-mediated responses had a reversal potential of approximately $-82 \mathrm{mV}$, consistent with mediation via $\mathrm{Cl}^{-}$channels. The reversal potential for the $\mathrm{GABA}_{\mathrm{B}}$ response was -97
$\mathrm{mV}$, consistent with it being a $\mathrm{K}^{+}$conductance. The roles of these GABA receptors in postsynaptic responses were also examined in interneurons. Optic tract stimulation evoked a disynaptic IPSP that was mediated by all three types of GABA receptors and depended on activation of geniculate interneurons. Stimulation of the thalamic reticular nucleus evoked an IPSP, which appeared to be mediated exclusively by bicuculline-sensitive $\mathrm{GABA}_{\mathrm{A}}$ receptors and depended on the activation of reticular cells. The results indicate that geniculate interneurons form a complex neuronal circuitry with thalamocortical and reticular cells via feed-forward and feedback circuits, suggesting that they play a more important role in thalamic function than thought previously.

Key words: dendrite; cortex; visual cortex; thalamus; thalamic reticular nucleus; lateral posterior nucleus; superior colliculus; inhibitory circuits; oscillation; epilepsy; $G A B A_{C}$ receptor; retina
The thalamus is the primary structure that relays sensory information from the periphery to the cortex in mammals (Sherman and Koch, 1986; Sherman and Guillery, 1996). The thalamus is also involved in normal and abnormal synchronized neuronal activity (Steriade et al., 1993; von Krosigk et al., 1993; Huguenard and Prince, 1994b; Warren et al., 1994). These sensory and oscillatory functions are primarily mediated by the three basic types of thalamic neurons (Jones, 1985): thalamocortical cells, local interneurons, and cells in the thalamic reticular nucleus (TRN cells or cells in the equivalent perigeniculate nucleus). Thalamocortical cells are excitatory neurons, and they alone have axons that project to the cortex. In contrast, local interneurons and TRN cells are GABAergic cells, and their axons project locally within the thalamus to form complex inhibitory circuits. The inhibitory circuits can provide different forms of inhibition on thalamocortical cells, which are not only important for sculpting ascending sensory signals (Norton and Godwin, 1992; Soltesz and Crunelli, 1992) but also for promoting and synchronizing the thalamic oscillations (Steriade et al., 1993, 1996).

Of those of the two broad classes of inhibitory neurons in the thalamus, the properties of inhibitory connections and synapses made by TRN cells have been well studied (Ahlsén et al., 1985; Lo, 1985; Crunelli et al., 1988; Thomson, 1988; Paré et al., 1991;

Received Dec. 28, 1998; revised April 21, 1999; accepted April 23, 1999.

This work was supported in part by the Chinese Academy of Sciences, the National Natural Science Foundation of China, and the Max-Planck Society. We thank Drs. Thomas Otis, Gerard Borst, Troy Margrie, Alex Reyes, Nail Burnashev, and Nathan Urban for their helpful discussions and comments.

Correspondence should be addressed to Dr. J. Julius Zhu, Cold Spring Harbor Laboratory, 1 Bungtown Road, Jones Building, Cold Spring Harbor, NY 11724.

Copyright (C) 1999 Society for Neuroscience $0270-6474 / 99 / 195721-10 \$ 05.00 / 0$
Huguenard and Prince, 1994a; Warren et al., 1994; Bal et al., 1995; Ulrich and Huguenard, 1996; Sanchez-Vives et al., 1997). It has been demonstrated that in addition to projecting their axons to the thalamic relay nuclei, TRN cells also form mutual inhibitory connections within the TRN. The mutual inhibitory connections, like those from TRN to thalamocortical cells, are mediated by both $\mathrm{GABA}_{\mathrm{A}}$ and $\mathrm{GABA}_{\mathrm{B}}$ receptors (Ulrich and Huguenard, 1996; Kim et al., 1997; Sanchez-Vives et al., 1997), which are believed to be crucial for TRN cells to mold their output patterns (i.e., burst or tonic) and subsequently to determine the forms of inhibition imposed on thalamocortical cells (Huguenard and Prince, 1994a; Destexhe and Sejnowski, 1995; Kim et al., 1997). In contrast, the inhibitory connections to local interneurons have not been well studied because in part of the technical difficulty of obtaining stable recording from these small cells (Ahlsén et al., 1984). Furthermore, the composition of GABA receptors involved in the inhibitory synapses on interneurons remains unclear. The whole-cell recording technique makes small neurons more accessible for intracellular recording (Hamill et al., 1981). Using this technique, we routinely obtained stable recordings from geniculate interneurons that lasted 1-4 hr, allowing us to examine both electrophysiological and pharmacological properties of the GABAergic synapses formed on interneurons. The results provide a more detailed description of the local inhibitory circuits in the thalamus.

\section{MATERIALS AND METHODS}

Experiments were performed in thalamic slices from Wistar rats. These animals were postnatal $30-60 \mathrm{~d}$ old $(100-280 \mathrm{gm})$, and no differences in electrophysiological properties of interneurons were found over this age range. The rats were deeply anesthetized by halothane and decapitated. 
Figure 1. A geniculate interneuron. $A$, Morphology of a reconstructed geniculate interneuron. $B$, Location of the cell in the LGN. Note that the coronal section contains no TRN. $v L G N$, Ventral LGN; $L P$, lateral posterior nucleus; $O T$, optic tract. $C$, Responses of the same interneuron to depolarizing and hyperpolarizing current pulses. The resting potential of this cell was $-76 \mathrm{mV}$.

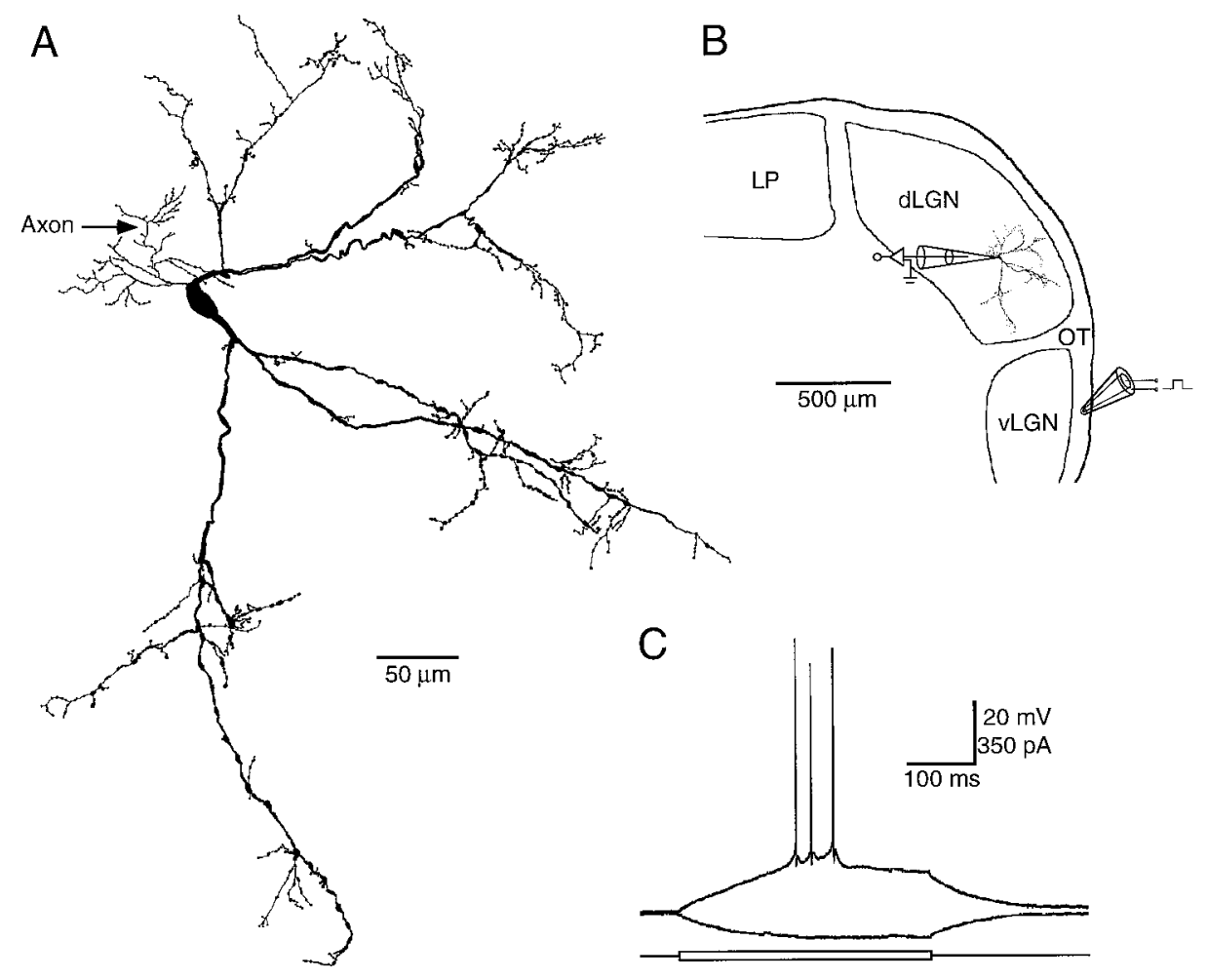

The brain was then quickly removed and placed into cold $\left(1-4^{\circ} \mathrm{C}\right)$ physiological solution containing (in $\mathrm{mm}$ ): $\mathrm{NaCl} 125, \mathrm{KCl} 2.5, \mathrm{NaH}_{2} \mathrm{PO}_{4}$ 1.25, $\mathrm{NaHCO}_{3} 25, \mathrm{MgCl}_{2} 1$, dextrose 25, and $\mathrm{CaCl}_{2} 2$, at $\mathrm{pH}$ 7.4. The solution was continuously bubbled with $95 \% \mathrm{O}_{2} / 5 \% \mathrm{CO}_{2}$. Slices containing LGN, each $300-500 \mu \mathrm{m}$ thick, were cut either coronally or parasagittally from the tissue blocks with a microslicer (Campden Instrument). These slices were kept in a warmed $\left(37.0 \pm 0.5^{\circ} \mathrm{C}\right)$, oxygenated physiological solution for $\sim 1 \mathrm{hr}$ before recordings were made. During the recordings, slices were submerged in a Plexiglas chamber and stabilized using a fine nylon net attached to a platinum ring. The chamber was perfused with warmed, oxygenated physiological solution, and the halftime for the bath solution exchange was $\sim 6 \mathrm{sec}$. The temperature of the bath solution in the chamber was kept at $35.0 \pm 0.5^{\circ} \mathrm{C}$. Agonists and antagonists were typically applied with the bath solution at 7-15 min intervals. Approximately 4-7 min was allowed to wash in and wash out the antagonists. Local application of glutamate within TRN was achieved by a brief application of pressure to the back of the pipette containing 250 $\mu \mathrm{M}$ glutamate in physiological solution (cf. Stuart and Sakmann, 1995). During this experiment, TRN was always on the downstream side of the bath solution flow, and a dye, pontamine sky blue, was included in the glutamate solution to make sure that glutamate did not spread into other nuclei.

Whole-cell recordings from interneurons were made either with the blind-patch technique (Blanton et al., 1989; Edwards et al., 1989) or with the aid of differential interference contrast optics (Stuart et al., 1993). Patch electrodes were made from borosilicate tubing, and their resistances were 5-9 $\mathrm{M} \Omega$ with our intracellular solution. The standard intracellular solution was (in $\mathrm{mM}$ ): potassium gluconate 115, HEPES 10, MgATP 2, $\mathrm{Na}_{2} \mathrm{ATP} 2$, GTP 0.3, and $\mathrm{KCl} 20$, with $0.25 \%$ biocytin, at $\mathrm{pH}$ 7.3. An $11 \mathrm{mV}$ liquid junction potential was subtracted from all membrane potentials. An Axoclamp-2B amplifier (Axon Instruments) was used to record voltage responses. The optic tract and TRN were stimulated by a concentric bipolar electrode (FHC Inc., Bowdoinham, ME) with single $(200 \mu \mathrm{sec} ; 15-115 \mu \mathrm{A} ; 0.25 \mathrm{~Hz}$ ) or short (three pulses at $100-400 \mathrm{~Hz}$ ) trains of current pulses. The recording traces typically contained single sweeps except for those (see Figs. $6 A, 7 A$ ) that had five superimposed sweeps. After recordings were made, slices were directly fixed by immersion in $4 \%$ paraformaldehyde in $0.1 \mathrm{M}$ phosphate buffer, resected into 150 - to $250-\mu \mathrm{m}$-thick sections, and histologically reacted for biocytin to recover the cell morphology (Horikawa and Armstrong, 1988). Cells were subsequently drawn at $100 \times$ magnification with the aid of a computerized reconstruction system (Neurolucida 3.18). Chemicals were purchased from Research Biochemicals (Natick, MA).

\section{RESULTS}

\section{Neuronal identification}

We studied inhibitory receptors and IPSPs in 60 interneurons in the rat's LGN using the whole-cell recording technique (Fig. 1). After the whole-cell configuration was formed, interneurons were easily identified by their characteristic physiological properties, such as high input resistance and long membrane time constant (Fig. 1C) (Leresche et al., 1991; Pape et al., 1994; Williams et al., 1996; Z hu and Uhlrich, 1997; Zhu et al., 1999b). The morphology of all 60 cells was recovered, confirming that the recordings were indeed obtained from interneurons (Grossman et al., 1973; Ohara et al., 1983; Ottersen and Storm-Mathisen, 1984; Webster and Rowe, 1984; Gabbott et al., 1985, 1986). Unlike thalamocortical cells, which have a relatively large soma and a multipolar appearance (Zhu and Uhlrich, 1997; Zhu et al., 1999a), interneurons typically had a bipolar appearance with two dendrites arising from the opposite sides of the soma (Fig. 1A). The two long complex dendrites, beaded and having intricate branching patterns, encompassed a relatively large area within the LGN (Fig. $1 B)$. Seven interneurons, however, had three complex dendrites arising from the soma (data not shown) (but see $\mathrm{Z}$ hu et al., 1999a). In most interneurons, a putative axon, with relatively fine caliber and frequent en passant varicosities, could be identified. The axon typically originated from the soma or a proximal dendrite and ramified locally within the LGN. The axonal and dendritic arbors tended to be spatially offset from each other, with the axon arbor occupying a relatively smaller area near the soma.

\section{$\mathrm{GABA}_{A}$ and $\mathrm{GABA}_{B}$ receptors in interneurons}

We first studied the responses of interneurons to GABA. A brief application $(5-7 \mathrm{sec})$ of $500 \mu \mathrm{M}$ GABA with the bath solution 
A GABA
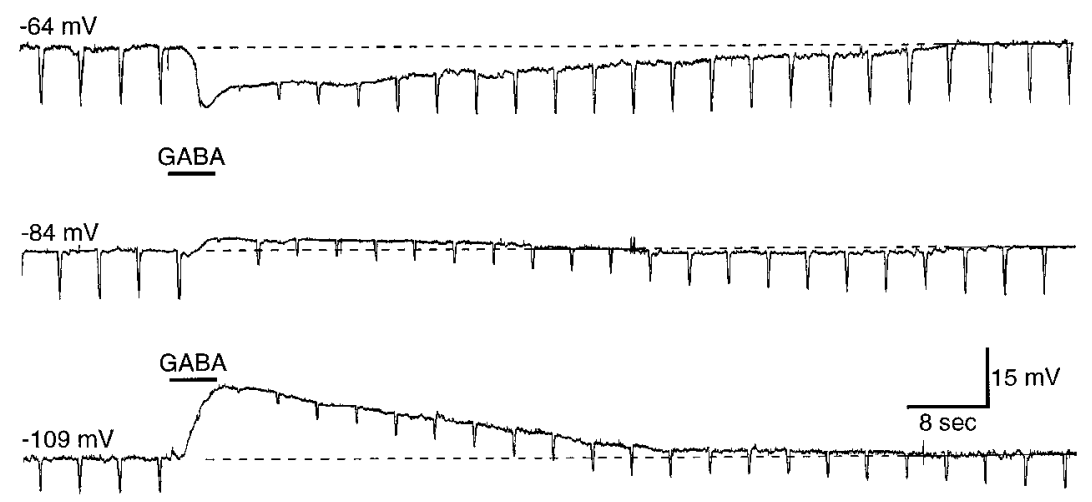

\section{B}
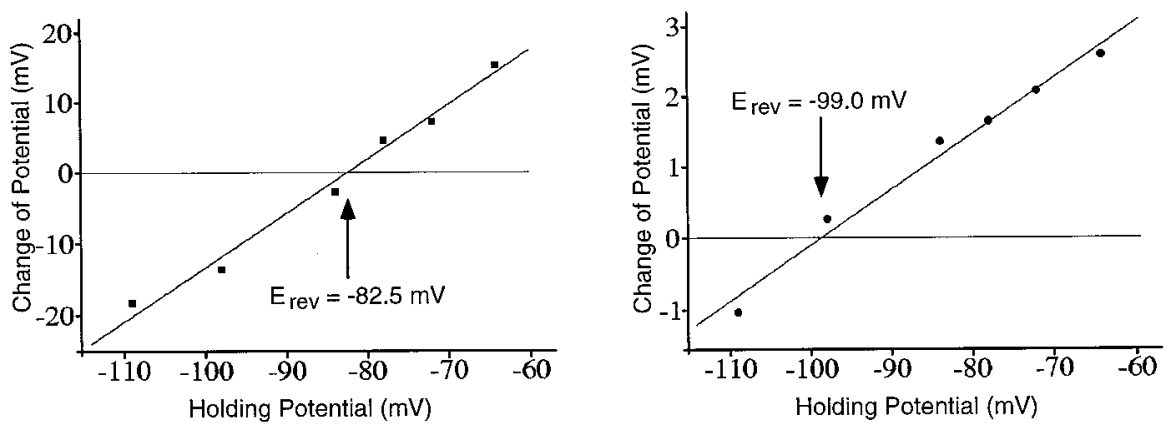

Figure 2. Responses of a rat geniculate interneuron to a brief bath application of GABA. $A$, GABA (500 $\mu \mathrm{M}$; horizontal bar) induced a prolonged response in a geniculate interneuron, which appeared to consist of two components. $B$, Plotting the peak amplitudes of the early response against the membrane potential revealed its reversal potential to be $-82.5 \mathrm{mV}$. $C$, Plotting the amplitudes of the response at $50 \mathrm{sec}$ after the GABA application against the membrane potential revealed its reversal potential to be $-99.0 \mathrm{mV}$. The data points in $B$ and $C$ were fitted by linear lines. The resting potential of this cell was $-64 \mathrm{mV}$. induced a prominent hyperpolarization at the resting or a slightly depolarized membrane potential (up to $-55 \mathrm{mV} ; n=33$; Fig. 2). The hyperpolarization lasted 50-80 sec and appeared to contain two components. The early component had a large amplitude (up to $25 \mathrm{mV}$ ) and fast time course and was accompanied by a large decrease in input resistance. In contrast, the later one had a small amplitude (up to $8 \mathrm{mV}$ ) and slow time course and was marked by a small reduction in input resistance (Fig. $2 A$ ). Plotting the peak amplitude of the early polarization against the holding potential gave the reversal potential of the early response to be $-81.5 \pm 3.2$ $\mathrm{mV}(n=9$; Fig. $2 B)$, whereas the reversal potential of the later response was $-97.2 \pm 2.3 \mathrm{mV}(n=9$; Fig. $2 C)$. The result suggests that the GABA responses in interneurons are mediated by at least two different conductances.

To examine whether the two GABA responses were mediated by $\mathrm{GABA}_{\mathrm{A}}$ and $\mathrm{GABA}_{\mathrm{B}}$ receptors, respectively, we performed a series of pharmacological experiments. The cells were initially hyperpolarized to approximately $-90 \mathrm{mV}$ to reverse the early GABA response (Fig. $3 A$ ). Adding $20 \mu \mathrm{M}$ bicuculline, a GABA receptor blocker (Sivilotti and Nistri, 1991; Thompson, 1994), suppressed the early depolarization, whereas the later hyperpolarization was little affected $(n=5$; Fig. $3 B)$. Adding $1 \mathrm{~mm}$ saclofen, a $\mathrm{GABA}_{\mathrm{B}}$ receptor blocker (Sivilotti and Nistri, 1991; Thompson, 1994), completely blocked the later hyperpolarization $(n=5$; Fig. $3 D)$. The results indicate that both $\mathrm{GABA}_{\mathrm{A}}$ and $\mathrm{GABA}_{\mathrm{B}}$ receptors are involved in the GABA responses in interneurons.

As shown in Figure 3, $20 \mu \mathrm{M}$ bicuculline only partially blocked the early depolarizing response (by $66.4 \pm 7.3 \% ; n=5$ ). Increasing bicuculline from 20 to $200 \mu \mathrm{M}$ had no additional effect on the residual depolarization ( $n=3$; Fig. $3 C$ ), indicating the existence of a bicuculline-resistant response. The reversal potential of the residual response was $-82.9 \pm 3.4 \mathrm{mV}(n=7)$, similar to that of the bicuculline-sensitive response. This response was also insensitive to $10 \mu \mathrm{M}$ strychnine ( $n=3$; data not shown), a glycine receptor blocker (Gillette and Dacheux, 1995). We speculated that it might be mediated by bicuculline-insensitive $\mathrm{GABA}_{\mathrm{A}}$ receptors and tested this hypothesis with picrotoxin (PTX), a $\mathrm{Cl}^{-}$channel blocker (Akaike et al., 1985), which blocks both bicuculline-sensitive and -insensitive $\mathrm{GABA}_{\mathrm{A}}$ responses (Lukasiewicz et al., 1994; Qian and Dowling, 1994). Bicuculline and saclofen were used to isolate the bicuculline-insensitive response (Fig. 4A,B). Adding $10 \mu \mathrm{M}$ PTX completely blocked the response $(n=5$; Fig. $4 C)$. The result suggests that bicucullineinsensitive $\mathrm{GABA}_{\mathrm{A}}$ receptors are also present in interneurons.

Bicuculline-insensitive $\mathrm{GABA}_{\mathrm{A}}$ receptors have been extensively studied in the retina (Feigenspan et al., 1993; Qian and Dowling, 1993; Lukasiewicz et al., 1994; Matthews et al., 1994). These studies have demonstrated that a conformationally restricted GABA analog cis-4-aminocrotonic acid (CACA) is a potent agonist for the bicuculline-insensitive $\mathrm{GABA}_{\mathrm{A}}$ receptors. To confirm that geniculate interneurons express two types of $\mathrm{GABA}_{\mathrm{A}}$ receptors, we also used CACA as the receptor agonist. Briefly applying $250 \mu \mathrm{M}$ CACA induced a hyperpolarization at the resting or a slightly depolarized potential (up to $-55 \mathrm{mV}$; Fig. $5 A$ ). The response lasted $\sim 40-50 \mathrm{sec}$ and had a reversal potential of $-82.2 \pm 2.7 \mathrm{mV}(n=5)$.

CACA can selectively activate bicuculline-insensitive $\mathrm{GABA}_{\mathrm{A}}$ receptors in some retinal neurons but not in other ones (Lukasiewicz et al., 1994; Gillette and Dacheux, 1995). We exam- 


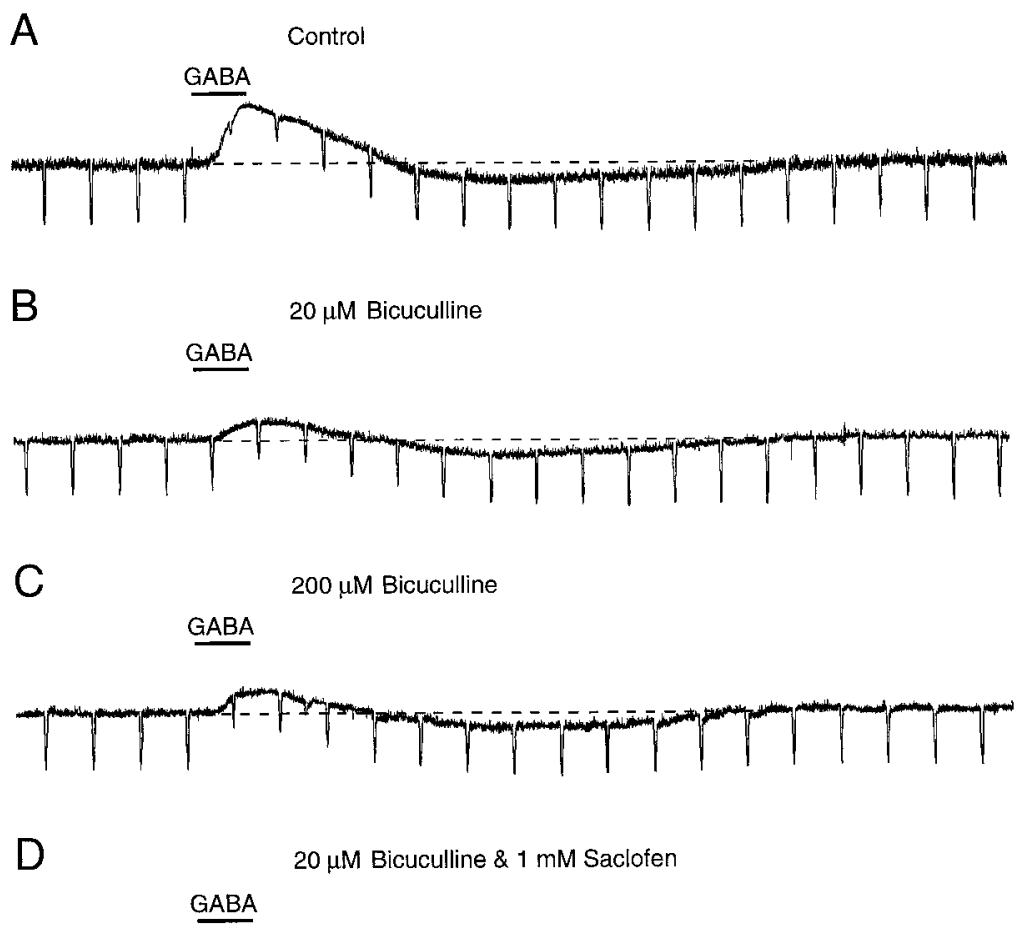

Figure 3. Responses of a rat geniculate interneuron to a brief bath application of GABA. $A$, A brief bath application of 500 $\mu \mathrm{M}$ GABA induced a depolarization and a hyperpolarization in an interneuron. $B$, The depolarization was suppressed by bath application of $20 \mu \mathrm{M}$ bicuculline. $C$, Increasing bicuculline to $200 \mu \mathrm{M}$ had little additional effect on the residual depolarization. $D$, Adding $1 \mathrm{~mm}$ saclofen in the bath solution completely blocked the hyperpolarization. $E$, The response recovered after washing in the normal bath solution. The resting membrane potential of this cell was $-61 \mathrm{mV}$, and the cell was held at -90 $\mathrm{mV}$ during the experiment.
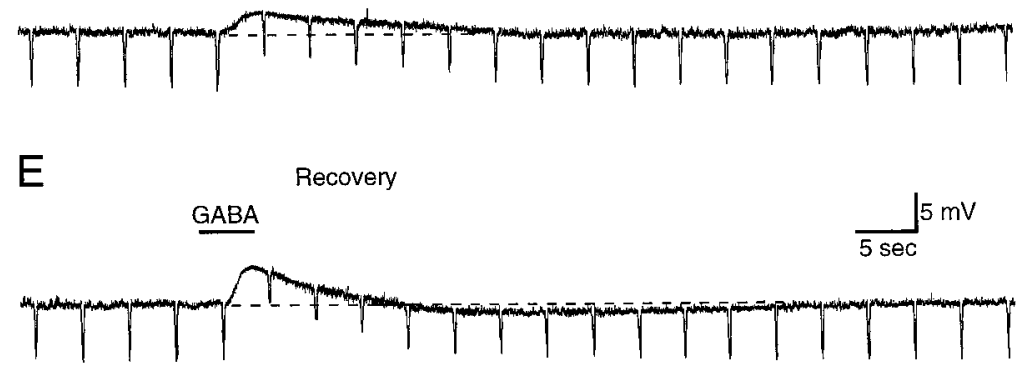

ined whether CACA can be used to activate bicucullineinsensitive $\mathrm{GABA}_{\mathrm{A}}$ receptors in interneurons selectively. Bath application of $20 \mu \mathrm{M}$ bicuculline blocked $66.0 \pm 10.0 \%$ of the CACA-induced hyperpolarization $(n=5$; Fig. $5 A, B)$, suggesting that CACA activated both bicuculline-sensitive and -insensitive $\mathrm{GABA}_{\mathrm{A}}$ receptors in interneurons. Adding bicuculline up to 200 $\mu \mathrm{M}$ had no additional effect $(n=3)$. The residual response reversed at $-83.5 \pm 3.0 \mathrm{mV}(n=3$; data not shown $)$ and was completely blocked by bath application of $10 \mu \mathrm{M}$ PTX $(n=5$; Fig. $5 C$ ), indicating a $\mathrm{Cl}^{-}$-dependent mechanism.

Together, the results suggest that the GABA-induced responses in interneurons are mediated by three types of GABA receptors: bicuculline-sensitive $\mathrm{GABA}_{\mathrm{A}}$ receptors, bicucullineinsensitive $\mathrm{GABA}_{\mathrm{A}}$ receptors, and $\mathrm{GABA}_{\mathrm{B}}$ receptors.

\section{Interneuron-mediated inhibition in interneurons}

To examine whether all three types of GABA receptors are involved in generating IPSPs in these interneurons, we studied the synaptic responses of these interneurons to stimulation of the optic tract and TRN.

We first investigated the responses induced by the optic tract stimulation, using only the coronal slices that did not contain TRN (Fig. 1B). A single electric shock induced a long-lasting EPSP in interneurons at the resting membrane potential, which could reach threshold and elicit action potentials (Fig. 6A). No obvious IPSP was detected in this condition, presumably because of the presence of the prolonged EPSP. However, when cells were depolarized to approximately $-5 \mathrm{mV}$, a prominent IPSP (peak amplitude, $16.6 \pm 2.4 \mathrm{mV} ; n=7$ ) was revealed (Fig. 6B). The IPSP lasted $293 \pm 19 \mathrm{msec}$ and consisted of a large, fast hyperpolarization and a small, slow tail. The fast hyperpolarization was primarily suppressed by bath application of $20 \mu \mathrm{M}$ bicuculline, leaving a small $(1.4 \pm 0.3 \mathrm{mV})$ but prolonged $(285 \pm 21 \mathrm{msec})$ hyperpolarization ( $n=7$; Fig. $6 C$ ). Adding $1 \mathrm{~mm}$ saclofen selectively blocked the later portion of the hyperpolarization $(n=7$; Fig. $6 D)$. Although the residual hyperpolarization $(0.9 \pm 0.2 \mathrm{mV}$; $153 \pm 14 \mathrm{msec}$ ) was little affected by additional bicuculline (up to $100 \mu \mathrm{M} ; n=2$; data not shown), it was completely abolished by 10 $\mu \mathrm{M} \operatorname{PTX}(n=7$; Fig. $6 E)$. Therefore, these results suggest that all three types of GABA receptors contribute to the optic tractevoked IPSP in interneurons.

We then tested whether the optic tract-elicited IPSP was dependent on the activation of interneurons. After the IPSP was induced by the optic tract stimulation (Fig. 7A,B), $20 \mu \mathrm{M} \mathrm{6,7-}$ dinitroquinoxaline-2,3-dione (DNQX), a kainate and AMPA receptor blocker, and $50 \mu \mathrm{M} \mathrm{D}(-)$-2-amino-5-phosphonopentanoic acid (D-AP-5), an NMDA receptor blocker, were applied with the bath solution. DNQX and D-AP-5 reversibly blocked the IPSP $(n=4$; Fig. $7 C, D)$. The results together suggest that the IPSP is 
A

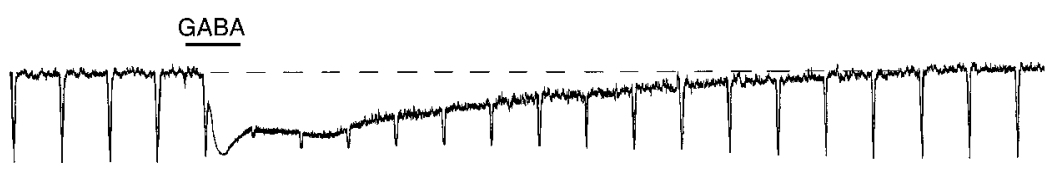

B

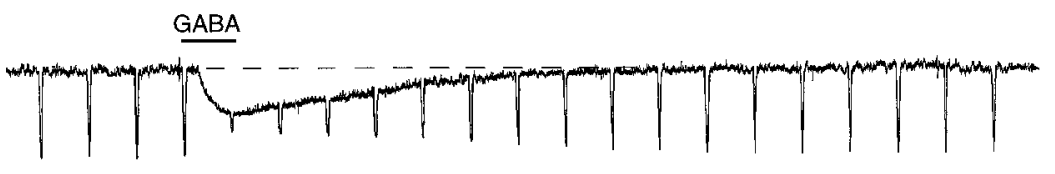

C

$20 \mu \mathrm{M}$ Bicuculline, $2 \mathrm{mM}$ Saclofen \& $10 \mu \mathrm{M}$ PTX

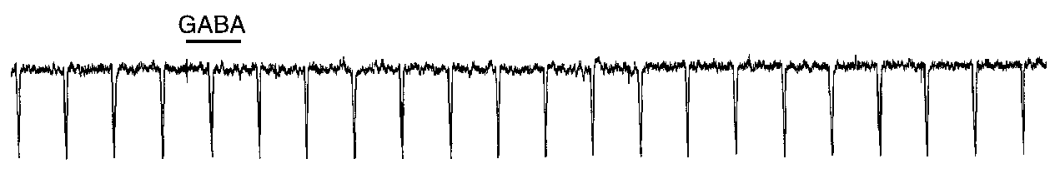

D Recovery

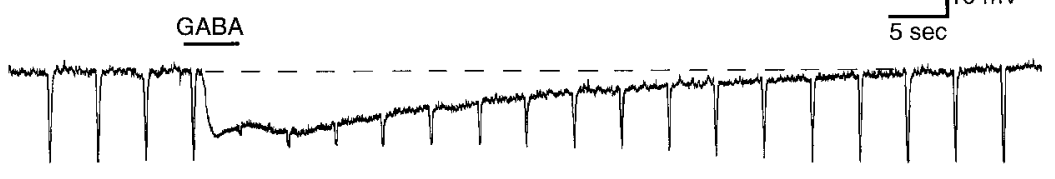

Figure 4. Responses of a rat geniculate interneuron to a brief bath application of GABA. $A$, A brief bath application of $500 \mu \mathrm{M}$ GABA induced a hyperpolarization in an interneuron. $B$, The hyperpolarization was partially blocked by bath application of $20 \mu \mathrm{m}$ bicuculline and $2 \mathrm{~mm}$ saclofen. $C$, The residual response was completely blocked by adding 10 $\mu \mathrm{M}$ PTX in the bath solution. $D$, The response partially recovered after washing in the normal bath solution. The resting membrane potential of this cell was $-63 \mathrm{mV}$. a disynaptic potential, resulting from the activation of interneurons. The results also indicate that the IPSP is mediated by three different types of GABA receptors.

\section{TRN cell-mediated inhibition in interneurons}

The TRN cell-mediated inhibition was also studied. We sectioned the slices parasagittally so that both the LGN and the visual sector of the TRN could be included in the same slice (Fig. $8 B$ ). We found no difference in electrophysiological properties between the interneurons recorded from coronally cut slices and those from sagittally cut ones (Figs. $1 C, 8 C$ ). The morphology of these cells was also similar (Figs. $1 A, 8 A$ ).

Because stimulating the TRN may excite interneurons by activating excitatory thalamocortical and corticothalamic fibers that pass through the nucleus, $20 \mu \mathrm{M}$ DNQX and $50 \mu \mathrm{M}$ D-AP-5 were included in the bath solution during the following experiments. Single electric shock in the TRN induced an IPSP in interneurons $(n=5$; Fig. $9 A$ ). It had a duration of $134 \pm 15 \mathrm{msec}$ and an amplitude of $0.43 \pm 0.16 \mathrm{mV}$. The duration and amplitude of the IPSP increased to $218 \pm 23 \mathrm{msec}$ and $1.74 \pm 0.60 \mathrm{mV}$, respectively, when a train of three shocks was applied (Fig. 9B). Application of $20 \mu \mathrm{M}$ bicuculline reversibly blocked the IPSP $(n=5$; Fig. $9 C, D)$, suggesting that the IPSP might be mediated exclusively by bicuculline-sensitive $\mathrm{GABA}_{\mathrm{A}}$ receptors.

To eliminate the possibility that the IPSP might result from the activation of inhibitory fibers bypassing the TRN, we also used another approach, local application of glutamate within the TRN, to activate TRN cells. Application of glutamate in the TRN induced a hyperpolarization in interneurons (Fig. 10 $A$ ). The hyperpolarization was reversibly blocked by $20 \mu \mathrm{M}$ bicuculline $(n=4$; Fig. $10 B, C)$. The result confirms that TRN cells form inhibitory synapses on interneurons and that the inhibition may be mediated exclusively by bicuculline-sensitive $\mathrm{GABA}_{\mathrm{A}}$ receptors.

\section{DISCUSSION}

In this study, we demonstrated that three different types of GABA receptors (bicuculline-sensitive $\mathrm{GABA}_{\mathrm{A}}$ receptors, bicuculline-insensitive $\mathrm{GABA}_{\mathrm{A}}$ receptors, and $\mathrm{GABA}_{\mathrm{B}}$ receptors) are present in rat geniculate interneurons. All three types of GABA receptors are involved in the interneuron-mediated inhibition, whereas only bicuculline-sensitive $\mathrm{GABA}_{\mathrm{A}}$ receptors appear to be involved in the TRN cell-mediated inhibition.

\section{Three types of GABA receptors in interneurons}

A recent study reported that all interneurons expressed $\mathrm{GABA}_{\mathrm{A}}$ receptors and that only a small fraction of them also had $\mathrm{GABA}_{\mathrm{B}}$ receptors (Williams et al., 1996). Another study (Pape and McCormick, 1995), however, suggested that both $\mathrm{GABA}_{\mathrm{A}}$ and $\mathrm{GABA}_{\mathrm{B}}$ receptors are present in interneurons. Our results are consistent with the latter findings in that although the $\mathrm{GABA}_{\mathrm{B}}$ receptor-mediated response was typically very small, GABA responses were always mediated by both $\mathrm{GABA}_{\mathrm{A}}$ and $\mathrm{GABA}_{\mathrm{B}}$ receptors in geniculate interneurons.

We found that the $\mathrm{GABA}_{\mathrm{A}}$ receptor-mediated response, induced by both GABA and CACA, had a reversal potential of approximately $-82 \mathrm{mV}$, which was comparable with that in thalamocortical cells (Huguenard and Prince, 1994b; SanchezVives and McCormick, 1997; Ulrich and Huguenard, 1997). This reversal potential is more negative than the calculated $\mathrm{Cl}^{-}$equilibrium potential $(-44 \mathrm{mV})$, suggesting that an active $\mathrm{Cl}^{-}$extrusion mechanism may also exist in interneurons (Ulrich and $\mathrm{Hu}-$ guenard, 1997). In addition, in this study, we showed that the reversal potential of the $\mathrm{GABA}_{\mathrm{B}}$ response was approximately $-97 \mathrm{mV}$, congruent with it being mediated by a $\mathrm{K}^{+}$conductance (the calculated $\mathrm{K}^{+}$equilibrium potential is $-100 \mathrm{mV}$ ).

The existence of bicuculline-insensitive $\mathrm{GABA}_{\mathrm{A}}$ receptors was first confirmed in the retina (Lukasiewicz et al., 1994; Qian and 
A Control

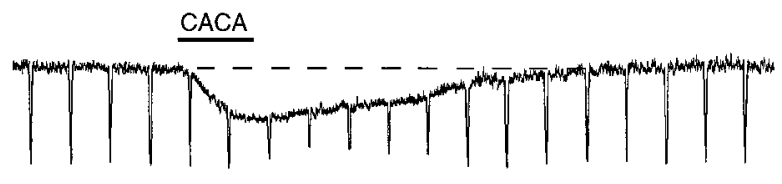

B

$20 \mu \mathrm{M}$ Bicuculline

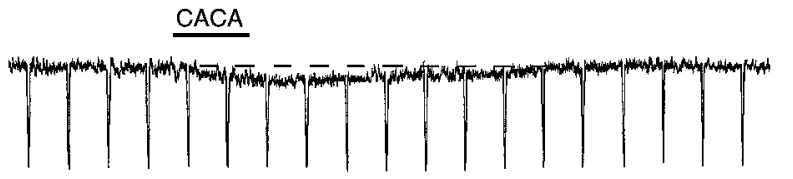

C

$20 \mu \mathrm{M}$ Bicuculline \& $10 \mu \mathrm{M}$ PTX
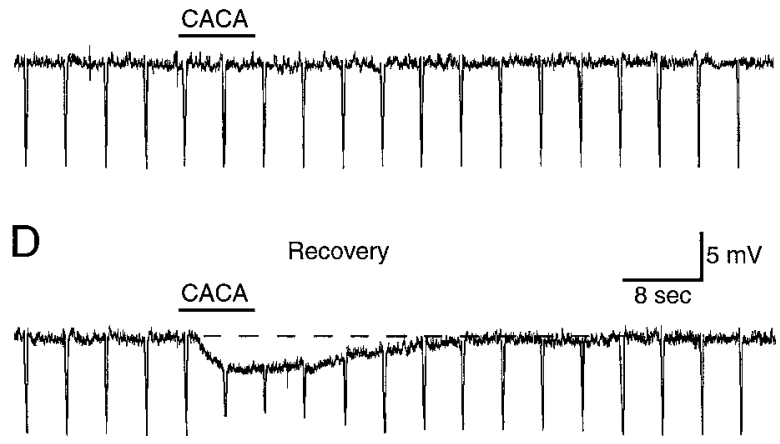

Figure 5. Responses of a rat geniculate interneuron to a brief bath application of CACA. $A$, A brief bath application of $250 \mu \mathrm{M}$ CACA induced a hyperpolarization in an interneuron. $B$, The hyperpolarization was partially blocked by bath application of $20 \mu \mathrm{M}$ bicuculline. $C$, The residual response was completely blocked by adding $10 \mu \mathrm{M}$ PTX in the bath solution. $D$, The response recovered after washing in the normal bath solution. The resting membrane potential of this cell was $-69 \mathrm{mV}$.

Dowling, 1994). The receptors, also named $\mathrm{GABA}_{\mathrm{C}}$ receptors, were found to be coupled with $\mathrm{Cl}^{-}$channels and sensitive to PTX (but see Feigenspan et al., 1993). There is evidence that the receptors might also exist in the other nuclei in the CNS (Drew et al., 1984; Sivilotti and Nistri, 1989). A recent molecular biological study has suggested that this type of receptor protein is expressed in the LGN, although restricted to a subgroup of geniculate neurons (Wegelius et al., 1998). Because thalamocortical cells in the LGN do not have bicuculline-resistant $\mathrm{GABA}_{\mathrm{A}}$ conductances (Crunelli et al., 1988; Bal et al., 1995), by default, the receptors must exist in the other group of cells in the LGN, namely, geniculate interneurons. Our finding that there is a bicuculline-insensitive $\mathrm{GABA}_{\mathrm{A}}$ response in geniculate interneurons is consistent with this notion. This is the first direct evidence that bicuculline-insensitive $\mathrm{GABA}_{\mathrm{A}}$ receptors mediate synaptic potentials in another region of the CNS besides the retina.

\section{Local inhibitory circuits in the thalamus}

We demonstrated that TRN cells inhibit interneurons in rats. This is in good agreement with our previous in vivo study in cats (Ahlsén et al., 1985). However, whether the similar connections exist in other mammals, such as ferrets, remains elusive (Bal et al., 1995; Sanchez-Vives and McCormick, 1997). Compared with the TRN cell-mediated IPSP in thalamocortical cells (Huguenard and Prince, 1994a), the TRN cell-mediated IPSP in interneurons had a relatively small amplitude. This may be because only a limited number of TRN cell-interneuron connections were pre- served in the slices. It is also possible that TRN cells form fewer synapses on interneurons than on thalamocortical cells, as suggested by a recent anatomical study (Liu et al., 1995). Interestingly, this TRN cell-mediated inhibition appeared to be mediated by $\mathrm{GABA}_{\mathrm{A}}$ receptors only. However, we cannot eliminate the possibility that $\mathrm{GABA}_{\mathrm{B}}$ receptors may also be activated in certain conditions [e.g., during the very strong activation of TRN cells and the accumulation of GABA at the synapses (Otis and Mody, 1992; Isaacson et al., 1993; Huguenard and Prince, 1994a; Kim et al., 1997)].

Our previous in vivo study suggested that the cortical stimulation can induce an IPSP in geniculate interneurons that is mediated by the inhibitory circuit from TRN cells (Ahlsén et al., 1985). However, whether there was an interneuron-mediated inhibition in interneurons is still unclear because the optic tract stimulationevoked IPSP may result from the activation of the recurrent inhibitory circuit alone (Ahlsén et al., 1985). Using the in vitro preparation, we could cut LGN slices that contained no TRN. Stimulation of the optic tract in these slices evoked a prominent IPSP in all geniculate interneurons recorded, suggesting the existence of an interneuron-mediated inhibition. This result was confirmed by bath application of DNQX and D-AP-5, which block excitatory retinogeniculate transmission (Scharfman et al., 1990; Zhu et al., 1999a). As expected, blocking the excitation of interneurons eliminated the IPSP. This result is in line with the anatomical finding that interneurons may form mutual inhibitory synaptic connections (Famiglietti, 1970; Wong, 1970; Lieberman and Webster, 1974; Pasik et al., 1976).

Our pharmacological experiments suggest that although three types of GABA receptors are involved in the interneuronmediated inhibition, only bicuculline-sensitive $\mathrm{GABA}_{\mathrm{A}}$ receptors may be involved in the TRN cell-mediated inhibition. From these experiments, together with the knowledge from previous in vivo (e.g., Ahlsén et al., 1985; Lo, 1985; Paré et al., 1991; Zhu and Lo, 1997, 1998) and in vitro studies (e.g., Crunelli et al., 1988; Thomson, 1988; Lo and Sherman, 1994; Bal et al., 1995; Ulrich and Huguenard, 1996), a more detailed picture of thalamic local inhibitory circuits has emerged. Figure 11 is a diagram for the thalamic local circuitry, which is simplified to emphasize its major characteristics. TRN cells receive excitatory inputs from thalamocortical cells and give feedback $\mathrm{GABA}_{\mathrm{A}}$ and $\mathrm{GABA}_{\mathrm{B}}$ receptormediated inhibition to thalamocortical cells. TRN cells also form mutual inhibitory connections mediated by both $\mathrm{GABA}_{\mathrm{A}}$ and $\mathrm{GABA}_{\mathrm{B}}$ receptors. In addition, TRN cells synapse on interneurons and inhibit them via $\mathrm{GABA}_{\mathrm{A}}$ receptors. As with thalamocortical cells, interneurons also receive excitatory inputs directly from ganglion cells in the retina. Besides forming mutual inhibitory connections via $\mathrm{GABA}_{\mathrm{A}}$ and $\mathrm{GABA}_{\mathrm{B}}$ receptors, interneurons also provide feed-forward inhibition to thalamocortical cells, which is mediated by both $\mathrm{GABA}_{\mathrm{A}}$ and $\mathrm{GABA}_{\mathrm{B}}$ receptors. It is still unclear whether interneurons receive synaptic inputs from thalamocortical cells, but the connections may be rare if they do exist (Friedlander et al., 1981; Montero, 1991).

\section{Functional considerations}

Three types of GABA receptors and two inhibitory pathways allow more controlling of the excitation and firing properties of interneurons (Connors et al., 1988; Connors, 1992; Ferster and Jagadeesh, 1992; Mody et al., 1994) and subsequently of the inhibition patterns imposed onto thalamocortical cells (Huguenard and Prince, 1994a; Destexhe and Sejnowski, 1995; Kim et 
A control

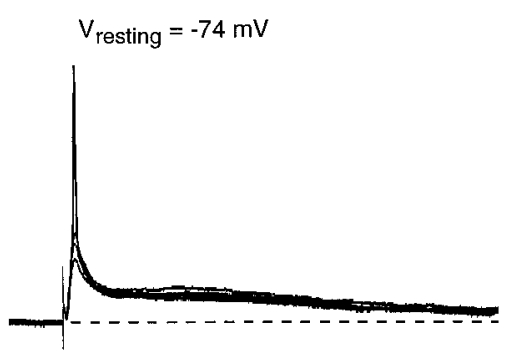

C Bicuculline

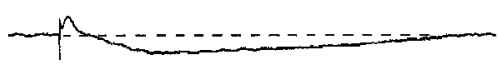

B Control

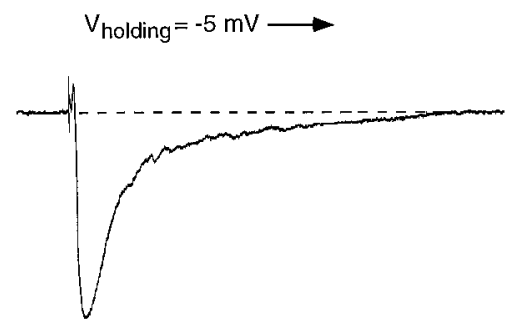

D Bicuculline \& Saclofen

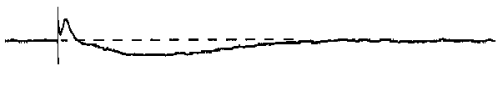

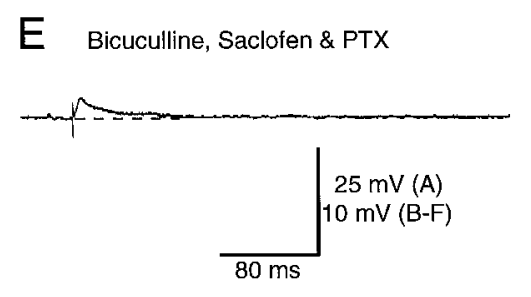

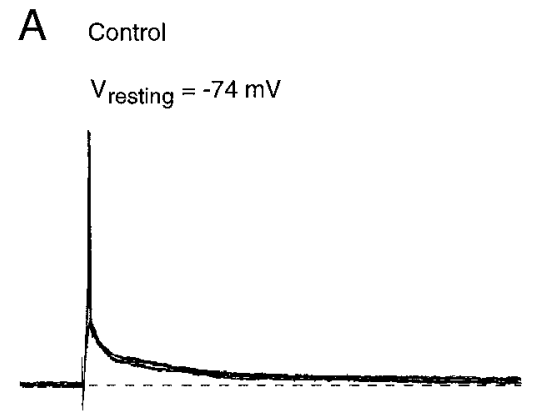

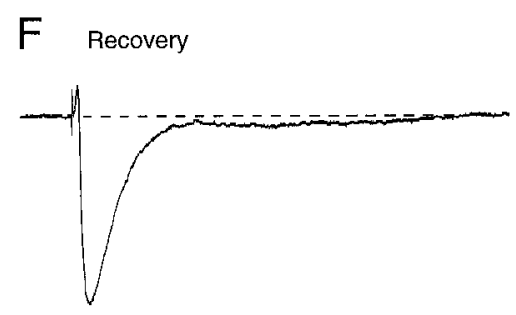

B Control

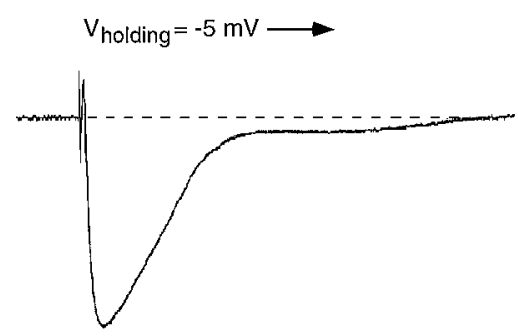

Figure 6. Responses of a rat geniculate interneuron to stimulation of the optic tract. $A$, Single electric shock induced a prolonged EPSP in an interneuron, which could reach threshold and elicit action potentials. $B$, Depolarizing the cell to $-5 \mathrm{mV}$ revealed a prominent IPSP. $C$, A substantial part of the IPSP was blocked by the bath application of $20 \mu \mathrm{M}$ bicuculline. $D$, The bicuculline-resistant IPSP was partially blocked by adding $1 \mathrm{~mm}$ saclofen to the bath solution. $E$, The residual IPSP was blocked by $10 \mu \mathrm{M}$ PTX. $F$, The response recovered after washing in the normal bath solution. The resting membrane potential of this cell was $-74 \mathrm{mV}$.

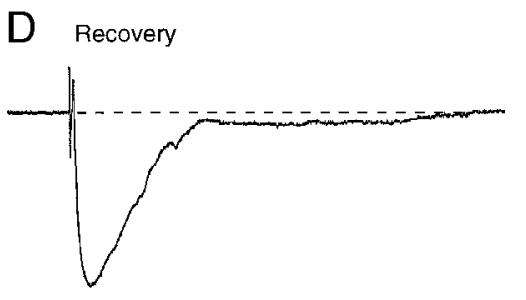

Figure 7. Responses of a rat geniculate interneuron to stimulation of the optic tract. $A$, Single electric shock induced a prolonged EPSP in an interneuron, which could reach threshold and elicit action potentials. $B$, Depolarizing the cell to $-5 \mathrm{mV}$ revealed a prominent IPSP. $C$, The IPSP was completely blocked by the bath application of $20 \mu \mathrm{M}$ DNQX and $50 \mu \mathrm{M}$ D-AP-5. D, The response recovered after washing in the normal bath solution. The resting membrane potential of this cell was $-74 \mathrm{mV}$.

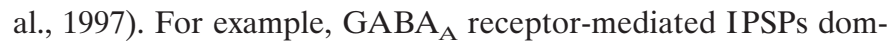
inated in interneurons and had a quick time course. They may provide robust suppression of the spiking activity with fine temporal control. GABA $\mathrm{B}_{\mathrm{B}}$ receptor-mediated IPSPs were very small and had a slow time course. They may elevate the threshold for spiking activity for a relatively long period. In addition, the feed-forward and feedback inhibitory circuits may affect the synaptic integration and spiking activity differently because the feedforward synapses possess both $\mathrm{GABA}_{\mathrm{A}}$ and $\mathrm{GABA}_{\mathrm{B}}$ receptors whereas the feedback synapses have only $\mathrm{GABA}_{\mathrm{A}}$ receptors. Furthermore, expressing two types of $\mathrm{GABA}_{\mathrm{A}}$ receptors in in- terneurons may also be of functional importance because preliminary evidence suggests that bicuculline-sensitive and -insensitive $\mathrm{GABA}_{\mathrm{A}}$ receptors might be located primarily in the soma/proximal dendrites and distal dendrites, respectively (J. J. Zhu and F.-S. Lo, unpublished observations). In geniculate interneurons, both the axon and dendrites can release neurotransmitter (Ralston, 1971; Cox et al., 1998). Thus, activation of $\mathrm{GABA}_{\mathrm{A}}$ receptors may regulate the dendritic release sites by reducing both dendritic excitation and calcium influx via bicuculline-insensitive $\mathrm{GABA}_{\mathrm{A}}$ receptors (Matthews et al., 1994; see also Kim et al., 1995; Chen and Lambert, 1997; Larkum et al., 1999) and may 


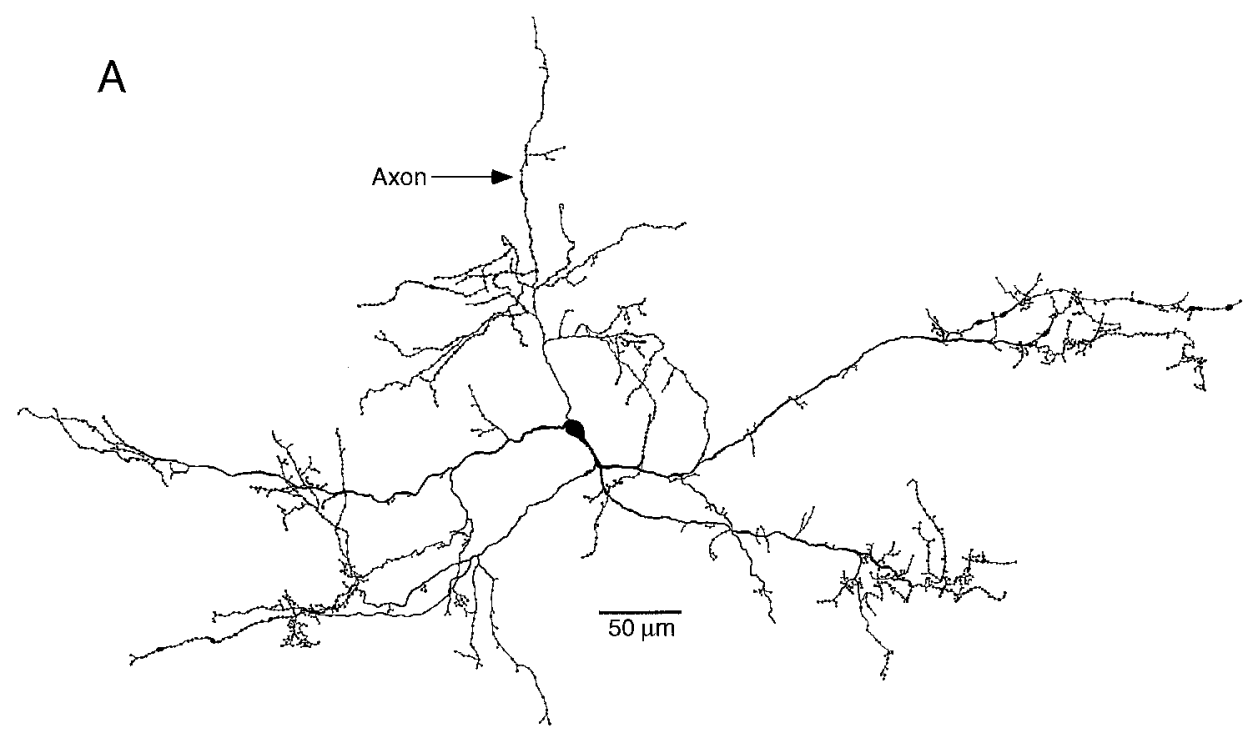

Figure 8. A geniculate interneuron. $A$, Morphology of a reconstructed geniculate interneuron. $B$, Location of the cell in the LGN. Note that the parasagittal section contains both the LGN and TRN. $M G$, Medial geniculate nucleus. $C$, Responses of the same interneuron to depolarizing and hyperpolarizing current pulses. The resting potential of this cell was $-67 \mathrm{mV}$.

B

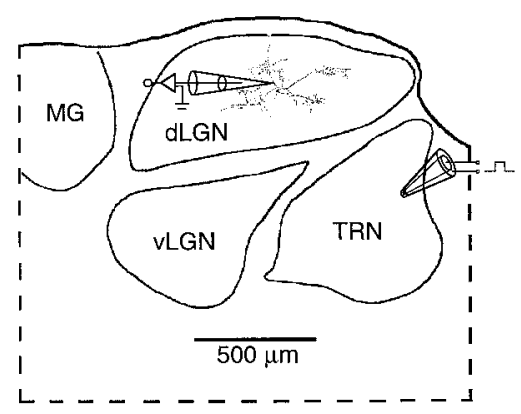

A control

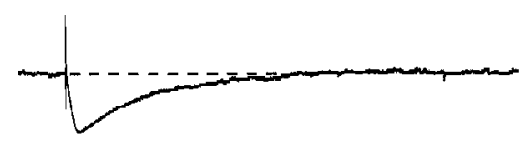

C

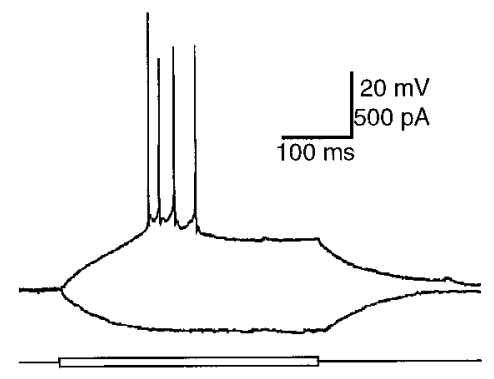

B Control

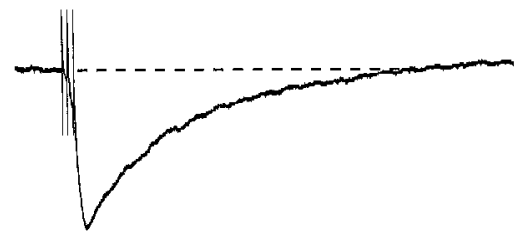

Figure 9. Responses of a rat geniculate interneuron to stimulation of the TRN. $A$, Single electric shock in the TRN induced a small IPSP in an interneuron. $B$, A train of three shocks at $250 \mathrm{~Hz}$ induced a larger IPSP in the same interneuron. $C$, The IPSP was completely blocked by the bath application of $20 \mu \mathrm{M}$ bicuculline. $D$, The response recovered after washing in the normal bath solution. Note that $20 \mu \mathrm{M}$ DNQX and $50 \mu \mathrm{M}$ D-AP-5 were included in the bath solution during the experiment. The resting membrane potential of this cell was $-66 \mathrm{mV}$.

\section{C $20 \mu \mathrm{M}$ Bicuculline}

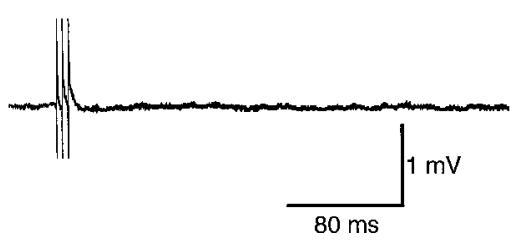

D Recovery

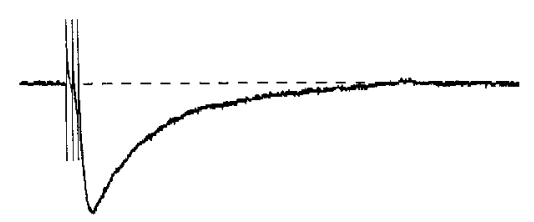

modulate the axonal release sites by suppressing the somatic excitation via bicuculline-sensitive $\mathrm{GABA}_{\mathrm{A}}$ receptors.

In addition to relaying the sensory information from the periphery to the cortex, the thalamus is also involved in the normal and abnormal oscillations (Steriade et al., 1993; von Krosigk et al., 1993; Huguenard and Prince, 1994b; Warren et al., 1994). Like thalamocortical cells and TRN cells, thalamic interneurons can generate an intrinsic oscillation (Zhu et al., 1999a) and partici- pate in the synchronized thalamic oscillations (Deschênes et al., 1984; Steriade and Deschênes, 1984). In the normal condition, interneurons may be involved in a 7-12 Hz oscillation (Deschênes et al., 1984; Zhu et al., 1999a). The mutual inhibitory connections between interneurons, which are mediated predominantly by $\mathrm{GABA}_{\mathrm{A}}$ receptors, are perfect for promoting and synchronizing this rhythm. However, if the $\mathrm{GABA}_{\mathrm{A}}$ inhibition is disabled and $\mathrm{GABA}_{\mathrm{B}}$ inhibition becomes dominant, the oscillation may trans- 
A

Control

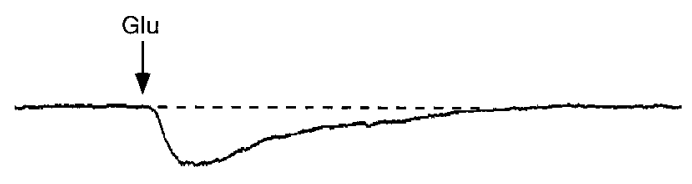

B

$20 \mu \mathrm{M}$ Bicuculline

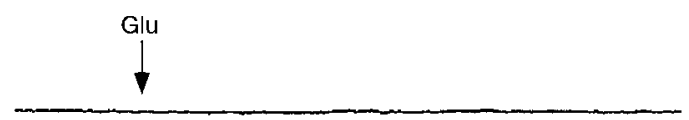

C

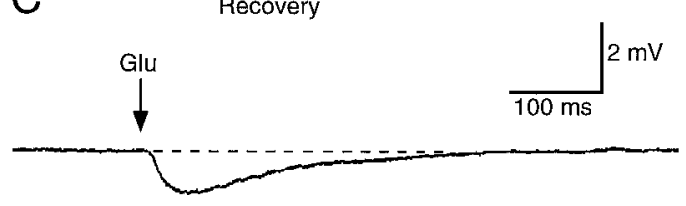

Figure 10. Responses of a rat geniculate interneuron to local application of glutamate in the TRN. $A$, Local application of $250 \mu \mathrm{M}$ glutamate in the TRN induced a small hyperpolarization in an interneuron. $B$, The hyperpolarization was completely blocked by the bath application of $20 \mu \mathrm{M}$ bicuculline. $C$, The response recovered after washing in the normal bath solution. The resting membrane potential of this cell was $-64 \mathrm{mV}$.

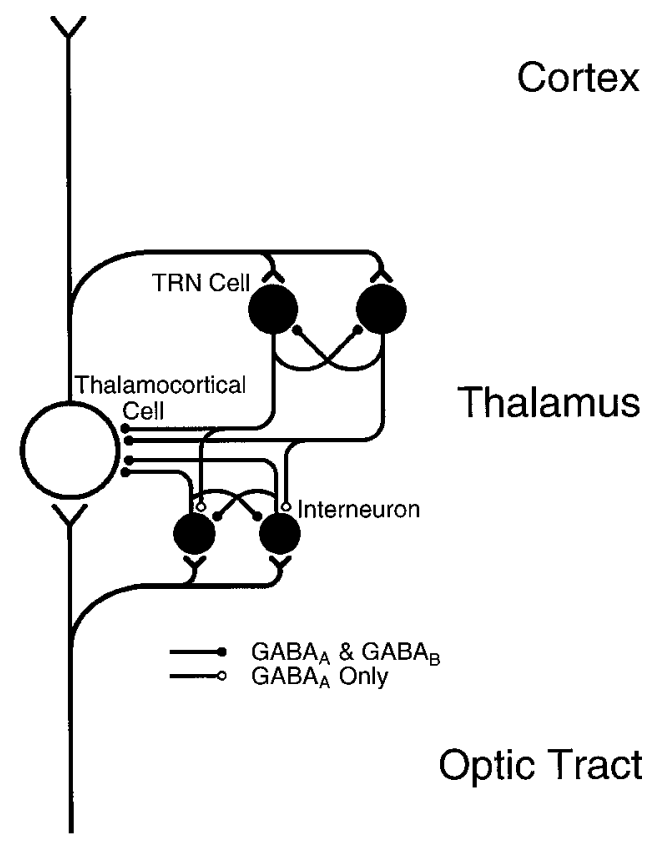

Figure 11. Inhibitory circuits in the thalamus.

form to the spike-and-wave activity (Bal et al., 1995; SanchezVives and McCormick, 1997), an epileptic type of oscillation that has been observed in interneurons in vivo (Steriade and Deschênes, 1984). The functional meaning of the TRN cellmediated inhibition in the thalamic oscillations is less obvious. However, the inhibition may be crucial for synchronizing the oscillations because its relatively small amplitude and brief time course appear to be ideal for interneurons to shift the oscillatory phase but not the oscillatory rhythm. Further study is necessary to determine the exact roles of individual cell- and receptor- mediated inhibitions in interneurons during these thalamic oscillations.

\section{REFERENCES}

Ahlsén G, Lindström S, Lo F-S (1984) Inhibition from the brain stem of inhibitory interneurones of the cat's dorsal lateral geniculate nucleus. J Physiol (Lond) 347:593-609.

Ahlsén G, Lindström S, Lo F-S (1985) Interaction between inhibitory pathway to principal cells in the lateral geniculate nucleus of the cat. Exp Brain Res 58:134-143.

Akaike N, Hattori K, Oomura Y, Carpenter DO (1985) Bicuculline and picrotoxin block gamma-aminobutyric acid-gated $\mathrm{Cl}^{-}$conductance by different mechanisms. Experientia 41:70-71.

Bal T, von Krosigk M, McCormick DA (1995) Role of the ferret perigeniculate nucleus in the generation of synchronized oscillations in vitro. J Physiol (Lond) 483:641-663.

Blanton MG, LoTurco TJ, Kriegstein AR (1989) Whole cell recording from neurons in slices of reptilian and mammalian cerebral cortex. J Neurosci Methods 30:203-210.

Chen H, Lambert NA (1997) Inhibition of dendritic calcium influx by activation of G-protein-coupled receptors in the hippocampus. J Neurophysiol 78:3484-3488.

Connors BW (1992) GABA $_{\mathrm{A}^{-}}$and $\mathrm{GABA}_{\mathrm{B}}$-mediated processes in visual cortex. Prog Brain Res 90:335-348.

Connors BW, Malenka RC, Silva LR (1988) Two inhibitory postsynaptic potentials, and $\mathrm{GABA}_{\mathrm{A}}$ and $\mathrm{GABA}_{\mathrm{B}}$ receptor-mediated responses in neocortex of rat and cat. J Physiol (Lond) 406:443-468.

Cox CL, Zhou Q, Sherman SM (1998) Glutamine locally activates dendritic outputs of thalamic interneurons. Nature 394:478-482.

Crunelli V, Haby M, Jassik-Gerschenfeld D, Leresche N, Pirchio M (1988) $\mathrm{Cl}^{-}$- and $\mathrm{K}^{+}$-dependent inhibitory postsynaptic potentials evoked by interneurones of the rat lateral geniculate nucleus. J Physiol (Lond) 399:153-176.

Deschênes M, Paradis M, Roy JP, Steriade M (1984) Electrophysiology of neurons of lateral thalamic nuclei in cat: resting properties and burst discharges. J Neurophysiol 51:1196-1219.

Destexhe A, Sejnowski TJ (1995) G protein activation kinetics and spillover of $\gamma$-aminobutyric acid may account for differences between inhibitory responses in the hippocampus and thalamus. Proc Natl Acad Sci USA 92:9515-9519.

Drew CA, Johnston GA, Weatherby RP (1984) Bicuculline-insensitive GABA receptors: studies on the binding of $(-)$-baclofen to rat cerebellar membranes. Neurosci Lett 52:317-321.

Edwards FA, Konnerth A, Sakmann B, Takahashi T (1989) A thin slice preparation for patch clamp recordings from neurons of the mammalian central nervous system. Pflügers Arch 414:600-612.

Famiglietti Jr EV (1970) Dendro-dendritic synapses in the lateral geniculate nucleus of the cat. Brain Res 20:181-191.

Feigenspan A, Wassle H, Bormann J (1993) Pharmacology of GABA receptor $\mathrm{Cl}^{-}$channels in rat retinal bipolar cells. Nature 361:159-162.

Ferster D, Jagadeesh B (1992) EPSP-IPSP interactions in cat visual cortex studied with in vivo whole-cell patch recording. J Neurosci 12:1262-1274.

Friedlander MJ, Lin CS, Stanford LR, Sherman SM (1981) Morphology of functionally identified neurons in lateral geniculate nucleus of the cat. J Neurophysiol 46:80-129.

Gabbott PLA, Somogyi J, Stewart MG, Hamori J (1985) GABAimmunoreactive neurons in the rat dorsal lateral geniculate nucleus: light microscopical observations. Brain Res 346:171-175.

Gabbott PLA, Somogyi J, Stewart MG, Hamori J (1986) A quantitative investigation of the neuronal composition of the rat dorsal lateral geniculate nucleus using GABA-immunocytochemistry. Neuroscience 19:101-111.

Gillette MA, Dacheux RF (1995) GABA- and glycine-activated currents in the rod bipolar cell of the rabbit retina. J Neurophysiol 74:856-875.

Grossman A, Lieberman AR, Webster KE (1973) A Golgi study of the rat dorsal lateral nucleus. J Comp Neurol 166:245-256.

Hamill OP, Narty A, Neher E, Sakmann B, Sigworth FJ (1981) Improved patch-clamp technique for high-resolution current recording from cells and cell-free membrane patches. Pflügers Arch 391:85-100.

Horikawa K, Armstrong WE (1988) A versatile means of intracellular labeling: injection of biocytin and its detection with avidin conjugates. J Neurosci Methods 25:1-11.

Huguenard JR, Prince DA (1994a) Clonazepam suppresses GABA $_{B^{-}}$ 
mediated inhibition in thalamic relay neurons through effects in nucleus reticularis. J Neurophysiol 71:2576-2581.

Huguenard JR, Prince DA (1994b) Intrathalamic rhythmicity studied in vitro: nominal T-current modulation causes robust antioscillatory effects. J Neurosci 14:5485-5502.

Isaacson JS, Solis JM, Nicoll RA (1993) Local and diffuse synaptic actions of GABA in the hippocampus. Neuron 10:165-175.

Jones EG (1985) The thalamus. New York: Plenum.

Kim HG, Beierlein M, Connors BW (1995) Inhibitory control of excitable dendrites in neocortex. J Neurophysiol 74:1810-1814.

Kim U, Sanchez-Vives MV, Mccormick DA (1997) Functional dynamics of GABAergic inhibition in the thalamus. Science 278:130-134.

Larkum ME, Zhu JJ, Sakmann B (1999) A new cellular mechanism for coupling inputs arriving at different cortical layers. Nature 398:338-341.

Leresche N, Lightowler S, Soltesz I, Jassik-Gerschenfeld D, Crunelli V (1991) Low-frequency oscillatory activities intrinsic to rat and cat thalamocortical cells. J Physiol (Lond) 441:155-174.

Lieberman AR, Webster KE (1974) Aspects of the synaptic organization of intrinsic neurons in the dorsal lateral geniculate nucleus. An ultrastructural study of the normal and of the experimentally deafferented nucleus in the rat. J Neurocytol 3:677-710.

Liu XB, Warren RA, Jones EG (1995) Synaptic distribution of afferents from reticular nucleus in ventroposterior nucleus of cat thalamus. J Comp Neurol 352:187-202.

Lo F-S (1985) Mutual inhibition between recurrent inhibitory interneurones in the geniculocortical pathway of the rabbit. Chin J Physiol Sci $3: 1-6$.

Lo F-S, Sherman SM (1994) Feedback inhibition in the cat's lateral geniculate nucleus. Exp Brain Res 100:365-368.

Lukasiewicz PD, Maple BR, Werblin FS (1994) A novel GABA receptor on bipolar cell terminals in the tiger salamander retina. J Neurosci 14:1202-1212.

Matthews G, Ayoub GS, Heidelberger R (1994) Presynaptic inhibition by GABA is mediated via two distinct GABA receptors with novel pharmacology. J Neurosci 14:1079-1090.

Mody I, De Koninck Y, Otis TS, Soltesz I (1994) Bridging the cleft at GABA synapses in the brain. Trends Neurosci 17:517-525.

Montero VM (1991) A quantitative study of synaptic contacts on interneurons and relay cells of the cat lateral geniculate nucleus. Exp Brain Res 86:257-270.

Norton TT, Godwin DW (1992) Inhibitory GABAergic control of visual signals at the lateral geniculate nucleus. Prog Brain Res 90:193-217.

Ohara PT, Lieberman AR, Hunt SP, Wu J-Y (1983) Neural elements containing glutamic acid decarboxylase (GAD) in the dorsal lateral geniculate nucleus of the rat: immunohistochemical studies by light and electron microscopy. Neuroscience 8:189-244.

Otis TS, Mody I (1992) Differential activation of GABA ${ }_{A}$ and GABA $_{B}$ receptors by spontaneously released transmitter. J Neurophysiol 67:227-235.

Ottersen OP, Storm-Mathisen J (1984) Glutamine- and GABAcontaining neurons in the mouse and rat brain, as demonstrated with a new immunocytochemical technique. J Comp Neurol 229:374-392.

Pape H-C, McCormick DA (1995) Electrophysiological and pharmacological properties of interneurons in the cat dorsal lateral geniculate nucleus. Neuroscience 68:1105-1125.

Pape H-C, Budde T, Mager R, Kisvarday ZF (1994) Prevention of $\mathrm{Ca}^{2+}$-mediated action potentials in GABAergic local circuit neurones of rat thalamus by a transient $\mathrm{K}^{+}$current. J Physiol (Lond) 478:403-422.

Paré D, Curró Dossi R, Steriade M (1991) Three types of inhibitory postsynaptic potentials generated by interneurons in the anterior thalamic complex of cat. J Neurophysiol 66:1190-1204.

Pasik P, Pasik T, Hamori J (1976) Synapses between interneurons in the lateral geniculate nucleus of monkeys. Exp Brain Res 25:1-13.

Qian H, Dowling JE (1993) Novel GABA responses from rod-driven retinal horizontal cells. Nature 361:162-164.

Qian H, Dowling JE (1994) Pharmacology of novel GABA receptors found on rod horizontal cells of the white perch retina. J Neurosci 14:4299-4307.

Ralston III HJ (1971) Evidence for presynaptic dendrites and a proposal for their mechanism of action. Nature 230:585-588.

Sanchez-Vives MV, McCormick DA (1997) Functional properties of perigeniculate inhibition of dorsal lateral geniculate nucleus thalamocortical neurons in vitro. J Neurosci 17:8880-8893.
Sanchez-Vives MV, Bal T, McCormick DA (1997) Inhibitory interactions between perigeniculate GABAergic neurons. J Neurosci 17:8894-8908.

Scharfman HE, Lu SM, Guido W, Adams PR, Sherman SM (1990) $\mathrm{N}$-Methyl-D-aspartate receptors contribute to excitatory postsynaptic potentials of cat lateral geniculate neurons recorded in thalamic slices. Proc Natl Acad Sci USA 87:4548-4552.

Sherman SM, Guillery RW (1996) Functional organization of thalamocortical relays. J Neurophysiol 76:1367-1395.

Sherman SM, Koch C (1986) The control of retinogeniculate transmission in the mammalian lateral geniculate nucleus. Exp Brain Res 63:1-20.

Sivilotti L, Nistri A (1989) Pharmacology of a novel effect of gammaaminobutyric acid on the frog optic tectum in vitro. Eur J Pharmacol 164:205-212.

Sivilotti L, Nistri A (1991) GABA receptor mechanisms in the central nervous system. Prog Neurobiol 36:35-92.

Soltesz I, Crunelli V (1992) GABA $_{A}$ and pre- and post-synaptic GABA ${ }_{B}$ receptor-mediated responses in the lateral geniculate nucleus. Prog Brain Res 90:151-169.

Steriade M, Deschênes M (1984) The thalamus as a neuronal oscillator. Brain Res 320:1-63.

Steriade M, McCormick DA, Sejnowski TJ (1993) Thalamocortical oscillations in the sleeping and aroused brain. Science 262:679-685.

Steriade M, Contreras D, Amzica F, Timofeev I (1996) Synchronization of fast $(30-40 \mathrm{~Hz})$ spontaneous oscillations in intrathalamic and thalamocortical networks. J Neurosci 16:2788-2808.

Stuart GJ, Sakmann B (1995) Amplification of EPSPs by axosomatic sodium channels in neocortical pyramidal neurons. Neuron 15:1065-1076.

Stuart GJ, Dodt HU, Sakmann B (1993) Patch-clamp recordings from the soma and dendrites of neurons in brain slices using infrared video microscopy. Pflügers Arch 423:511-518.

Thompson SM (1994) Modulation of inhibitory synaptic transmission in the hippocampus. Prog Neurobiol 42:575-609.

Thomson AM (1988) Inhibitory postsynaptic potentials evoked in thalamic neurons by stimulation of the reticularis nucleus evoke slow spikes in isolated rat brain slices. Neuroscience 25:491-502.

Ulrich D, Huguenard JR (1996) GABA $_{\mathrm{B}}$ receptor-mediated responses in GABAergic projection neurones of rat nucleus reticularis thalami in vitro. J Physiol (Lond) 493:845-854.

Ulrich D, Huguenard JR (1997) Nucleus-specific chloride homeostasis in rat thalamus. J Neurosci 17:2348-2354.

von Krosigk M, Bal T, McCormick DA (1993) Cellular mechanisms of a synchronized oscillation in the thalamus. Science 261:361-364.

Warren RA, Agmon A, Jones EG (1994) Oscillatory synaptic interactions between ventroposterior and reticular neurons in mouse thalamus in vitro. J Neurophysiol 72:1993-2003.

Webster MJ, Rowe MH (1984) Morphology of identified relay cells and interneurons in the dorsal lateral nucleus of the rat. Exp Brain Res $56: 468-474$.

Wegelius K, Pasternack M, Hiltunen JO, Rivera C, Kaila K, Saarma M, Reeben M (1998) Distribution of GABA receptor rho subunit transcripts in the rat brain. Eur J Neurosci 10:350-357.

Williams SR, Turner JP, Anderson CM, Crunelli V (1996) Electrophysiological and morphological properties of interneurones in the rat dorsal lateral geniculate nucleus in vitro. J Physiol (Lond) 490:129-147.

Wong MTT (1970) Somato-dendritic and dendro-dendritic synapses in the squirrel monkey lateral geniculate nucleus. Brain Res 20:135-139.

Zhu JJ, Lo F-S (1997) Recurrent inhibitory interneurons of the rabbit's lateral posterior-pulvinar complex. J Neurophysiol 78:3117-3124.

Zhu JJ, Lo F-S (1998) Control of recurrent inhibition of the lateral posterior-pulvinar complex by afferents from the deep layers of the superior colliculus of the rabbit. J Neurophysiol 80:1122-1131.

Zhu JJ, Uhlrich DJ (1997) Nicotinic receptor-mediated responses in relay cells and interneurons in the rat lateral geniculate nucleus. Neuroscience 80:191-202.

Zhu JJ, Lytton WW, Xue J-T, Uhlrich DJ (1999a) An intrinsic oscillation in interneurons of the rat lateral geniculate nucleus. J Neurophysiol 81:702-711.

Zhu JJ, Uhlrich DJ, Lytton WW (1999b) Properties of a hyperpolarization-activated cation current in interneurons in the rat lateral geniculate nucleus. Neuroscience 92:445-457. 